\title{
FIBER FLAX GERMINATION AT DIFFERENT TEMPERATURES AND SALINITY STRESS CONDITIONS
}

\author{
Ivana VARGA, Monika TKALEC KOJIĆ, D. ILJKIĆ, \\ Mirta RASTIJA, Manda ANTUNOVIĆ \\ Faculty of Agrobiotechnical sciences Osijek \\ Fakultet agrobiotehničkih znanosti Osijek
}

\section{SUMMARY}

In this study the fiber flax (Linum usitassimum L.) cultivar Lirina was tested to seed germination under salinity of $\mathrm{NaCl}$ and two different temperatures. The experiment was set up in controlled conditions in fitotron (Aralab). There were two temperatures $\left(10^{\circ} \mathrm{C}\right.$ and $\left.20^{\circ} \mathrm{C}\right)$ and different $\mathrm{NaCl}$ water solution used for salinity stress: $0 \mathrm{mM}, 20 \mathrm{mM}, 40 \mathrm{mM}, 60 \mathrm{mM}, 80$ $\mathrm{mM}$ and $100 \mathrm{mM}$. There were 100 seeds sown in 4 replications. The germination energy (\%) and germination rate (\%) were determined on $3^{\text {rd }}$ and $7^{\text {th }}$ day, respectively. At the lower temperature $\left(10^{\circ} \mathrm{C}\right)$ the seeds were not sprouted on $3^{\text {rd }}$ day, whereas at higher temperature $\left(20^{\circ} \mathrm{C}\right)$ mean germination energy was $31 \%$. Germination rate $\left(7^{\text {th }}\right.$ day) was quite similar at both temperatures $\left(58 \%\right.$ at $10^{\circ} \mathrm{C}$ and $59 \%$ at $\left.20^{\circ} \mathrm{C}\right)$. The higher salinity stress of 80 and $100 \mathrm{mM}$ had negative influence on germination energy as well germination rate. With increased salinity, the total seedlings length was also decreased. With increased salinity (over $20 \mathrm{mM}$ ), the total seedlings length was also decreased. In out study, low salinity stress of $20 \mathrm{mM}$ even increased the germination rate and germination energy and resulted with the longest seedlings of the fiber flax cultivar Lirina.

Key words: fiber flax, $\mathrm{NaCl}$, temperature, germination, seedlings

\section{INTRODUCTION}

Fibre flax (Linum usitatissimum L.) can be used either for the fiber extraction or for the seed production (linseed). Their seeds are rich in oil and protein, so they are used for production of linseed oil (Laza and Georgeta, 2012). According to historical records, the earliest example of preserved linen appears to be a needle-netted linen headpiece from Nahal Hemar Cave in Israel 8500 years ago, and Swiss Lake Dwellers used a native flax to make cloth 5000-6000 years ago (D e b n a t h, 2017). Flax fibers are soft with fineness and flexibility. Flax is grown in Western Europe, Eastern Europe, China, and Egypt (Kozlowski et al., 2005). The main production area is Western 
Ivana Varga et al.: Fiber flax germination at different temperatures and salinity stress conditions

Europe, and particularly France. In the Republic of Croatia, the fiber flax production is almost gone and it is grown on small areas, about 15 to 30 ha (Butorac et al., 2010; Pospišil, 2013; Butorac et al., 2017).

The germination process incorporates those events that commence with the uptake of water by the quiescent dry seed and terminate with the elongation of the embryonic axis (B e w l e y, 1997; B u k v i ć et al., 2015). Soil salinity is a common problem over the world, especially in areas with water deficit and irrigation water supply for field crops. $\mathrm{NaCl}$ may be inhibitory to the activities of some enzymesthat may play critical roles in seed germination ( $\mathrm{K}$ a t e $\mathrm{m} \mathrm{b}$ e et al., 1998). In recent decades the scientists over the world made considerable improvements in crop species by conventional selection and breeding techniques (A f 1 a k i, et al. 2017; Markulj Kulundžić et al., 2016). According to Mahajan and Tuteja (2005), understanding the mechanism of stress tolerance along with a plethora of genes involved in stress signalling network is important for crop improvement. Studies with seeds and early seedlings have great importance in evaluating the early growth of the plants under stress conditions ( $\mathrm{S}$ o $\mathrm{n} \mathrm{g}$ et al., 2008; Kaymakanova, 2009; N i m a c et al., 2018; B u r a nj i et al., 2019). The studies on halophytes are also very interesting, due to their salt tolerance ( $\mathrm{T}$ o b e et al., 2004; J a m i 1 et al. 2006; P a n u c ci o et al., 2014; Orlovsky et al., 2016).

The objective of the present study was to analyse fiber flax seed germination in salt stress conditions ( 0 to $100 \mathrm{mM} \mathrm{NaCl}$ ) and seedlings morphologyat two temperatures $\left(10\right.$ and $\left.20^{\circ} \mathrm{C}\right)$.

\section{MATERIAL AND METHODS}

Fiber flax cultivar Lirina (RWA) was used in this study. The study was set up in the Laboratory of plant analysis at the Faculty of Agrobiotechnical Sciences in Osijek, Republic of Croatia. The germination test of salt stress and temperatures was set up in the controlled conditions in the growth chamber (Fitoclima, Aralab) at $24 \mathrm{~h}$ dark conditions. The germination test was done according to the International Seed Testing Association - ISTA (ISTA, 2006). Before seting up the experiment, flax seeds were prechilled at temperature $8^{\circ}$ for 7 days. There were different temperatures tested $\left(10^{\circ} \mathrm{C}\right.$ and $\left.20^{\circ} \mathrm{C}\right)$ and salinity stress levels $(0,20,40,60,80$ and $100 \mathrm{mM} \mathrm{NaCl}$ water solutions). The granulated $\mathrm{NaCl}$ was used for the water solutions of different molarity. There were $55 \mathrm{ml}$ of saline water solution added on the filter paper (Munktell, $580 \mathrm{x}$ $580 \mathrm{~mm}, 80 \mathrm{~g} / \mathrm{qm}$ ) before the sowing. The seeds were sown on thewet filter paper (within the filter paper) in 4 replications.The filter paper was then rolled, marked and put into clean plastic bag. Every replication consisted 100 seeds. After 3 days the germination energy (\%) was determined by counting the seeds which had started to germinate. Then, after 7 days the final germination rate (\%) was determined, by counting all the germinated seeds.

After germination energy and germination rate determination 25 seedlings per replication were chosen randomly in order to measure the length of the seedlings root, 
Ivana Varga et al.: Fiber flax germination at different temperatures and salinity stress conditions

stem and total seedlings length $(\mathrm{cm})$. At the temperature of $10^{\circ} \mathrm{C}$ there was only total length of the seedlings determined since the seedlings were small and there was no clear difference between root and stem.

The results were transformed into Microsoft Office Excel programme and the statistical analysis was done using SAS Enterprise Guide 7.1.The grouping means was done by the Fisher LSD method at $95 \%$ confidence.

\section{RESULTS AND DISCUSSION}

At $10^{\circ} \mathrm{C}$ on the $3^{\text {rd }}$ day no seeds geminated, but on the $7^{\text {th }}$ day germination rate was $58 \%$ (Table 1). The mean germination energy in our study at $20^{\circ} \mathrm{C}$ was $31 \%$, while the germination rate was similar at both temperatures tested.

Table 1 Germination energy (\%) and germination rate $(\%)$ with regard to temperature and salinity Tablica 1. Energija klijanja (\%) i ukupna klijavost (\%) ovisno o temperaturi i salinitetu

\begin{tabular}{lcccc}
\hline & Germination energy, $3^{\text {rd }}$ day $(\%)$ & \multicolumn{2}{c}{ Germination rate, $7^{\text {th }}$ day $(\%)$} \\
\hline $\mathrm{NaCl}$ & $10^{\circ} \mathrm{C}$ & $20^{\circ} \mathrm{C}$ & $10^{\circ} \mathrm{C}$ & $20^{\circ} \mathrm{C}$ \\
\hline $0 \mathrm{mM}$ & & 31 & 61 & 60 \\
$20 \mathrm{mM}$ & & 35 & 66 & 65 \\
$40 \mathrm{mM}$ & 0 & 33 & 61 & 61 \\
$60 \mathrm{mM}$ & & 34 & 64 & 59 \\
$80 \mathrm{mM}$ & & 27 & 43 & 53 \\
$100 \mathrm{mM}$ & & 28 & 50 & 58 \\
\hline Mean & 0 & 31 & 58 & 59 \\
\hline
\end{tabular}

Even though from the previous study on $\mathrm{pH}$ and temperature influence on germination of fiber flax cultivar Lirina (B u r a n j i et al., 2019) it was determined that the period of 7 days was not enough to develop the seedlings with clear root and stem limit at $10^{\circ} \mathrm{C}$. The salinity experiment was conducted at $10^{\circ} \mathrm{C}$ temperature, due to fiber flax time of sowing, which is in Republic of Croatia from $15^{\text {th }}$ March to $15^{\text {th }}$ April, when the temperatures are not higher. $\mathrm{K} \mathrm{u} \mathrm{r} \mathrm{t}$ and Bozkurt (2006) tested 5 temperatures $\left(10,15,20,25\right.$ and $\left.30^{\circ} \mathrm{C}\right)$ and they also found that total percentage of seedling emergence and seedling emergence rate of varieties were significantly affected by the temperature, but the accelerated seedling emergence rate was fastest at 30 and slowest at $10^{\circ} \mathrm{C}$. On the contrary, in pots experiment, $\mathrm{O}^{\prime} \mathrm{c}$ o $\mathrm{n} n$ o $\mathrm{r}$ and Gusta (1994) found that temperature had no effect on flax germination, so the time for $50 \%$ of the seeds to germinateat $5 " \mathrm{C}$ was on average $160 \mathrm{~h}$ compared with $30 \mathrm{~h}$ at $15^{\prime \prime C}$. K u r t (2012) reported that the optimum temperatures of flax cultivars Antares and Bionda were found to be 22.10 and and $22.05{ }^{\circ} \mathrm{C}$. High temperatures have a negative influence on flax germinatios.

In our study the salinity had significant $(\mathrm{p}<0.05)$ influence on seedlings elongation (Table 2). With increasing salinity, the total seedlings length was decreased on both temperatures tested. The average for all salinity levels, the seedlings length after 7 days 
Ivana Varga et al.: Fiber flax germination at different temperatures and salinity stress conditions

on $10^{\circ} \mathrm{C}$ was $0.4 \mathrm{~cm}$, whereas at $20^{\circ} \mathrm{C}$ it was $10.7 \mathrm{~cm}$. The seedlings length at $20^{\circ} \mathrm{C}$ varied from $9.8 \mathrm{~cm}(100 \mathrm{mM})$ to $12.7 \mathrm{~cm}(20 \mathrm{mM})$. Increasing the $\mathrm{NaCl}$ salinity $(40-$ $100 \mathrm{mM}$ ), the total length was decreased. But, it was interesting to find that small salinity $(20 \mathrm{mM} \mathrm{NaCl})$ at $20^{\circ} \mathrm{C}$ significantly $(\mathrm{p}<0.05)$ increased the total length of the seedlings as compared to the control.

Table 2 The length $(\mathrm{cm})$ of the fiber flax seedlings at different $\mathrm{NaCl}$ water solution

Tablica 2. Dužina klijanaca predivog lana ovisno o zaslanjenosti vodene otopine $\mathrm{s} \mathrm{NaCl}$

\begin{tabular}{|c|c|c|c|c|}
\hline $\mathrm{NaCl}$ & $\begin{array}{l}\text { Total seedling } \\
\text { length }\left(10^{\circ} \mathrm{C}\right)\end{array}$ & $\begin{array}{l}\text { Total seedling } \\
\text { lenght }\left(20^{\circ} \mathrm{C}\right)\end{array}$ & Root length $\left(20^{\circ} \mathrm{C}\right)$ & Stem length $\left(20^{\circ} \mathrm{C}\right)$ \\
\hline $0 \mathrm{mM}$ & $0.6^{\mathrm{a}}$ & $11.3^{\mathrm{c}}$ & $6.1^{b}$ & $5.1^{b}$ \\
\hline $20 \mathrm{mM}$ & $0.5^{b}$ & $12.7^{\mathrm{a}}$ & $7.1^{\mathrm{a}}$ & $5.6^{\mathrm{a}}$ \\
\hline $40 \mathrm{mM}$ & $0.4^{\mathrm{c}}$ & $10.3^{c}$ & $5.4^{\mathrm{c}}$ & $4.9^{b}$ \\
\hline $60 \mathrm{mM}$ & $0.4^{\mathrm{c}}$ & $10.4^{\mathrm{c}}$ & $5.4^{\mathrm{c}}$ & $4.9^{b}$ \\
\hline $80 \mathrm{mM}$ & $0.3^{d}$ & $9.9^{\mathrm{c}}$ & $5.8^{\mathrm{bc}}$ & $4.1^{\mathrm{c}}$ \\
\hline $100 \mathrm{mM}$ & $0.2^{\mathrm{d}}$ & $9.8^{b}$ & $5.6^{\mathrm{bc}}$ & $4.2^{c}$ \\
\hline Mean & 0.4 & 10.7 & 5.9 & 4.8 \\
\hline
\end{tabular}

The differences marked with letter ${ }^{(\mathrm{a}, \mathrm{b}, \mathrm{c})}$ in the column at $95 \%$ confidence

The histograms (Figure 1) show that in the control at $10^{\circ} \mathrm{C}$ most of the seedlings were between 0.7 and $0.8 \mathrm{~cm} \mathrm{(32)} \mathrm{long,} \mathrm{whereas} \mathrm{in} \mathrm{the} \mathrm{control} \mathrm{at} 20^{\circ} \mathrm{C}$ most of the seedlings were in the range of 11.7 and $14.1 \mathrm{~cm}$ long (27). At the highest salinity, up to $100 \mathrm{mM}$, the most common length of fiber flax seedlings at $10^{\circ} \mathrm{C}$ was in the range of 0.2 to $0.3 \mathrm{~cm}(40)$ and at $20^{\circ} \mathrm{C}$ the most common seedlings length was in the range of 9.5 and $10.6 \mathrm{~cm}(28)$.

Under salt stress conditions elongation rate of the coleoptiles may decrease by low soil water potential (F r a n c o is et al., 1986). According to K a t e m b e et al. (1998.) in some cases, $\mathrm{NaCl}$ in the cytoplasm can result in toxic accumulation of a particular ion or decreased availability of some essential nutrients, but the authors also stated that ion toxicity of the $\mathrm{Na}^{+}$and $\mathrm{Cl}^{-}$ions in the cells may induce changes in protein activity because ions affect the structure of the hydration water which surrounds the protein molecule. For the salt tolerant flax varieties, Q a y y u m et al. (2019) stated that they had high potential to check $\mathrm{Na}^{+}$entry to the upper parts of plant and bind more $\mathrm{Na}^{+}$in their roots in comparison of salt sensitive genotypes, but also proved themselves as the high accumulator to $\mathrm{K}^{+}$in stems. In Canada, B e k e and Volkmar (1995) found that cation concentration $\left(\mathrm{Na}^{+}, \mathrm{K}^{+}, \mathrm{Ca}^{+}, \mathrm{Mg}^{2+}\right)$ in plant flax tops from saline soil decreased with physiological age and that flax tops on saline soil had higher $\mathrm{Mg}^{2+}$ and $\mathrm{Na}^{+}$ concentrations. 
Ivana Varga et al.: Fiber flax germination at different temperatures and salinity stress conditions
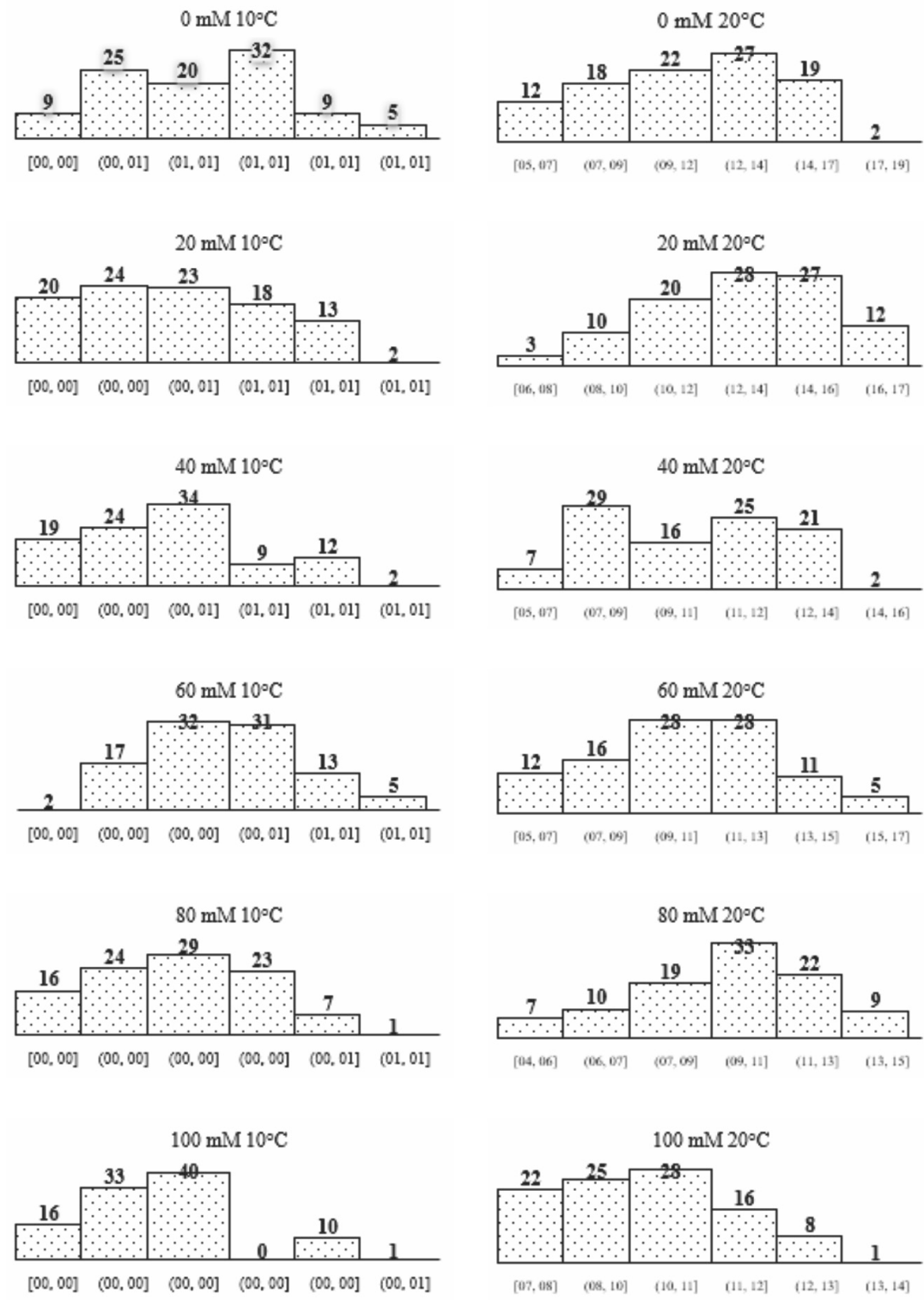

Figure 1 The histograms of total flax seedlings length $(\mathrm{cm})$ regard to salinity and temperature Grafikon 1. Histogrami ukupne dužine klijanaca predivog lana ovisno o salinitetu i temperaturi 
Ivana Varga et al.: Fiber flax germination at different temperatures and salinity stress conditions

Moghaddam et al. (2018) used six kinds of salts with concentrations of 0,50 , 100 and $200 \mathrm{mM}$. The author found that flax seeds were able to germinate even in 200 $\mathrm{mM} \mathrm{NaCl}$ and that germination at various salts was in the order of $\mathrm{NaCl}>\mathrm{CaCl}_{2}>\mathrm{KCl}>$ $\mathrm{Na}_{2} \mathrm{CO}_{3}>\mathrm{Na}_{2} \mathrm{SO}_{4}>\mathrm{CaCO}_{3}$. Sabei et al. (2007) found that for physiological parameters the sodium chloride inhibited germination via osmotic and toxic effects, so that seed viability was altered, especially in flax cultivar(H52). Moreover, authors found that at $200 \mathrm{mM} \mathrm{NaCl}$, lipid mobilization was delayed in the earliest germination phases.

A t w a and Elgazzar (2013) examine the tolerance of seven flax varieties in Egypt (Sakha 1, Sakha 2, Sakha 101, Sakha 102, Eclena, Elona and Esclena) on soil salinity. The authors found that under salinity stress conditions, the flax straw and seed yield decrease, but also the technical length $(\mathrm{cm})$ of the stem and stem radius $(\mathrm{mm})$ was also decreased.

\section{CONCLUSION}

In this study the salinity stress conditions were examined in order to above their influence on fiber flax cultivar Lirina germination energy, germination rate and seedlings morphology. Increasing salinity with $\mathrm{NaCl}$ up to 80 and $100 \mathrm{mM}$ negatively effects the germination energy and germination rate. Low level of salinity, of $20 \mathrm{mM}$ had a positive effect on germination energy $\left(35 \%\right.$ on $\left.20^{\circ} \mathrm{C}\right)$, germination rate $(66 \%$ at $10^{\circ} \mathrm{C}$ and $65 \%$ at $20^{\circ} \mathrm{C}$ ) and seedings elongation. Moreover, at $20 \mathrm{mM}$ seedlings developed the longest root $(7.1 \mathrm{~cm})$ and stem $(5.6 \mathrm{~cm})$. This cultivar could be grown even on the soils with salinity problem, but for the further conclusions, the agronomic value and fiber yields lists should also be conducted.

\section{KLIJAVOST PREDIVOG LANA PRI RAZLIČITIM TEMPERATURAMA U UVJETIMA SOLNOG STRESA}

\section{SAŽETAK}

Cilj istraživanja bio je utvrditi energiju klijanja (\%), ukupnu klijavost (\%) te dužinu klijanaca u uvjetima solnog stresa $(0 \mathrm{mM}, 20 \mathrm{mM}, 40 \mathrm{mM}, 60 \mathrm{mM}$, $80 \mathrm{mMi} 100 \mathrm{mM})$ na dvije temperature $\left(10\right.$ i $\left.20{ }^{\circ} \mathrm{C}\right)$. Eksperiment je postavljen u kontroliranim uvjetima $u$ fitotronu (Aralab). U istraživanje je bila uključena sorta predivog lana (Linum usitassimum L.) Lirina. Posijano je 100 sjemenki u 4 ponavljanja. Energija klijanja (\%) i klijavost (\%) određeni su trećeg, odnosno sedmog dana. Na nižoj temperaturi $\left(10{ }^{\circ} \mathrm{C}\right)$ sjeme nije proklijalo 3. dan, dok je pri višoj temperaturi $\left(20{ }^{\circ} \mathrm{C}\right)$ prosječna energija klijanja bila $31 \%$. Ukupna klijavost (7. dan) bila je podjednaka za obje temperature $\left(58 \%\right.$ na $10^{\circ} \mathrm{C}$ i $59 \%$ na $\left.20{ }^{\circ} \mathrm{C}\right)$. Općenito je veći solni stres od 
80 i $100 \mathrm{mM}$ smanjio energiju klijanja i ukupnu klijavost. S povećanjem zaslanjenosti preko $20 \mathrm{mM}$, ukupna duljina klijanaca predivog lana je također smanjena. Pri tretmanu $20^{\circ} \mathrm{C}$ uz $20 \mathrm{mM}$, čak je povećana ukupna klijavost, energija klijanja i dužina klijanaca, u odnosu na kontrolu i ostale razine zaslanjenosti za sortu Lirina.

Ključne riječi: predivi lan, $\mathrm{NaCl}$, temperatura, klijavost, klijanci

\section{REFERENCES}

1. Aflaki, F., Sedghi, M., Pazuki, A., Pessarakli, M. (2017): Investigation of seed germination indices for early selection of salinity tolerant genotypes: A case study in wheat. Emirates Journal of Food and Agriculture, 222-226.

2. Atwa, A. A. E., Elgazzar, A. A. M. (2013): Tolerance of some flax varieties to soil salinity. Journal of Soil Sciences and Agricultural Engineering, 4(5), 475-484.

3. Beke, G. J., Volkmar, K. M. (1995): Mineral composition of flax (Linum usitatissimum L.) and safflower (Carthamus tinctorius L.) on a saline soil high in sulfate salts. Canadian journal of plant science, 75(2), 399-404.

4. Bewley, J. D. (1997): Seed germination and dormancy. The plant cell, 9 (7), 1055.

5. Bukvić, G., Gantner, R., Grljušić, S., Popović, B., Agić, D. iStanisavljević, A. (2015): Effects of storage period and temperature upon seed and seedling traits of perennial ryegrass (Lolium perenne L.). Poljoprivreda, 21 (2), 3-9.

6. Buranji, I., Varga, I., Lisjak, M., Iljkić, D., Antunović, M. (2019): Morphological characteristic of fiber flax seedlings regard to different $\mathrm{pH}$ water solution and temperature. Journal of Central European Agriculture 20 (4), 1135-1142.

7. Butorac, J., Pospišil, M., Mustapić, Z., Marković, Z. (2010): Utjecaj prihrane dušikom na neka morfološka i fenološka svojstva sorata predivog lana. Sjemenarstvo, 27 (1-2), 19-29.

8. Butorac, Jasminka, Pospišil, M., Augustinović, Z. (2017): Utjecaj gnojidbe dušikom na prinos i sastavnice prinosa sjemena nekih sorata predivog lana. Sjemenarstvo, br. 30 (1-2): 11-25.

9. Debnath, S. (2017): Sustainable production of bast fibres. In Sustainable Fibres and Textiles. Woodhead Publishing, pp. 69-85.

10. Francois, L. E., Maas, E. V., Donovan, T. J., Youngs, V. L. (1986): Effect of Salinity on Grain Yield and Quality, Vegetative Growth, and Germination of Semi-Dwarf and Durum Wheat1. Agronomy Journal, 78(6), 1053-1058.

11. ISTA (2006): ISTA Handbook on Seedling Evaluation. Third edition. The International Seed Testing Association (ISTA). Bassersdorf, Switzerland.

12. Jamil, M., Deog Bae, L., Kwang Yong, J., Ashraf, M., Sheong Chun, L., EuiShik, R. (2006): Effect of salt $(\mathrm{NaCl})$ stress on germination and early seedling growth of four vegetables species. Journal of Central European Agriculture, 7(2), 273-282.

13. Katembe, W. J., Ungar, I. A., Mitchell, J. P. (1998): Effect of salinity on germination and seedling growth of two Atriplex species (Chenopodiaceae). Annals of Botany, 82 (2), 167-175.

14. Kaymakanova, M. (2009): Effect of salinity on germination and seed physiology in bean (Phaseolus vulgaris L.). Biotechnology \& Biotechnological Equipment, 23(sup1), 326-329.

15. Kozlowski, R., Baraniecki, P., \&Barriga-Bedoya, J. (2005): Bast fibres (flax, hemp, jute, ramie, kenaf, abaca). Biodegradable and sustainable fibres, 36-88.

16. Kurt, O. (2012): A predictive model for the effects of temperature on the germination period of flax seeds (Linum usitatissimum L.). Turkish Journal of Agriculture and Forestry, 36(6), 654-658.

17. Kurt, O., Bozkurt, D. (2006): Effect of temperature and photoperiod on seedling emergence of flax (Linum usitatissimum L.). Journal of Agronomy, 5 (3), 541-545.

18. Laza, A., Pop, G. (2012): The influence of fertilization and seeding density on flax oil production quality. Research Journal of Agricultural Science, 44 (4), 96-102. 
19. Mahajan, S., Tuteja, N. (2005): Cold, salinity and drought stresses: an overview. Archives of biochemistry and biophysics, 444(2), 139-158.

20. Markulj Kulundžić, A., Kovačević, J., Viljevac Vuletić, M., Josipović, A., Liović, I., Mijić, A., Lepeduš, H., Matoša Kočar, M. (2016): Impact of abiotic stress on photosynthetic efficiency and leaf temperature in sunflower. Poljoprivreda, 22 (2), 17-22.

21. Moghaddam, M., Babaei, K., Saeedi Pooya, E. (2017): Germination and growth response of flax (Linum usitatissimum) to salinity stress by different salt types and concentrations. Journal of Plant Nutrition, 41(5), 563-573.

22. Nimac, A., Lazarević, B., Petek, M., Vidak, M., Šatović, Z., Carović-Stanko, K. (2018): Effects of Salinity and Seed Priming on Germination of Sea Fennel (Crithmum maritimum L.). Agriculturae Conspectus Scientificus, 83 (2), 181-185.

23. O'Connor, B. J., Gusta, L. V. (1994): Effect of low temperature and seeding depth on the germination and emergence of seven flax (Linum usitatissimum L.) cultivars. Canadian Journal of Plant Science, 74(2), 247-253.

24. Orlovsky, N., Japakova, U., Zhang, H., Volis, S. (2016): Effect of salinity on seed germination, growth and ion content in dimorphic seeds of Salicornia europaea L. (Chenopodiaceae). Plant diversity, 38(4), 183-189.

25. Panuccio, M. R., Jacobsen, S. E., Akhtar, S. S., Muscolo, A. (2014): Effect of saline water on seed germination and early seedling growth of the halophyte quinoa. AoB plants, 6 .

26. Pospišil, M. (2013): Ratarstvo II dio - industrijsko bilje. Zrinski d.d. Čakovec, pp. 169 - 201.

27. Qayyum, M. A., Bashir, F., Maqbool, M. M., Ali, A., Bashir, S., Abbas, Q. (2019): Implications of saline water irrigation for linseed on seed germination, seedling survival and growth potential. Sarhad Journal of Agriculture, 35 (4), 1289-1297.

28. Sebei, K., Debez, A., Herchi, W., Boukhchina, S., \&Kallel, H. (2007): Germination kinetics and seed reserve mobilization in two flax (Linum usitatissimum L.) cultivars under moderate salt stress. Journal of Plant Biology, 50 (4), 447-454.

29. Song, J., Fan, H., Zhao, Y., Jia, Y., Du, X., Wang, B. (2008): Effect of salinity on germination, seedling emergence, seedling growth and ion accumulation of a euhalophyte Suaeda salsa in an intertidal zone and on saline inland. Aquatic Botany, 88 (4), 331-337.

30. Tobe, K., Li, X., Omasa, K. (2004): Effects of five different salts on seed germination and seedling growth of Haloxylon ammodendron (Chenopodiaceae). Seed Science Research, 14 (4), 345-353.

Author's address - Adrese autora:

Ivana Varga, e-mail: ivana.varga@fazos.hr

Monika Tkalec Kojić

D. Iljkić,

Mirta Rastija,

Manda Antunović

Josip Juraj Strossmayer University of Osijek,

Faculty of Agro biotechnical Sciences Osijek,

Department of Crop Production and Biotechnology,

Vladimira Preloga 1, 31000 Osijek, Republic of Croatia
Received - Primljeno:

03.06.2020. 